xyms

Culture and Politics

in Indonesia 


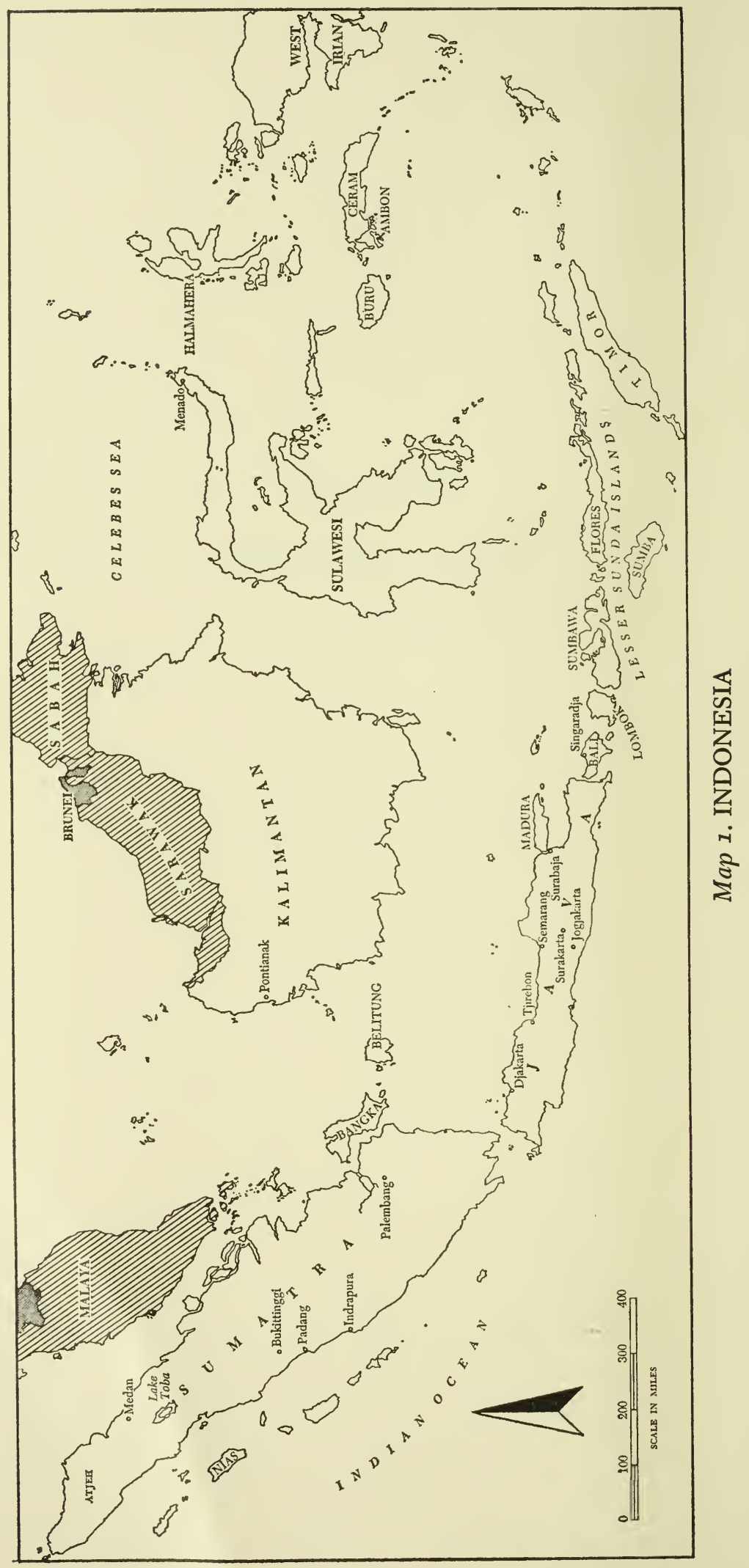




\section{Culture and Politics in Indonesia}

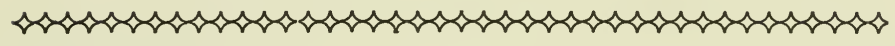

\section{Edited by CLAIRE HOLT}

with the assistance of

Benedict R. O'G. Anderson

and James Siegel

Cornell University Press 
Copyright (c) 1972 by Cornell University

All rights reserved. Except for brief quotations in a review, this book, or parts thereof, must not be reproduced in any form without permission in writing from the publisher. For information address Cornell University Press, 124 Roberts Place, Ithaca, New York 14850.

First published 1972 by Cornell University Press.

Published in the United Kingdom by Cornell University Press Ltd., 2-4 Brook Street, London W1Y IAA.

Prepared under the auspices of The Asia Society

This book has been published with the aid of a grant from the Hull Memorial Publication Fund of Cornell University.

International Standard Book Number o-8014-0665-X

Library of Congress Catalog Card Number 78-162538

PRINTED IN THE UNITED STATES OF AMERICA BY VAIL-BALLOU PRESS, INC.

Librarians: Library of Congress cataloging information appears on the last page of the book. 